\title{
ANALISIS KESTABILAN \\ MODEL PENYEBARAN PENYAKIT TUBERKULOSIS DENGAN LAJU INFEKSI TERSATURASI \\ (STABILITY ANALYSIS OF \\ TUBERCULOSIS DISEASE SPREAD MODEL CONSIDERING SATURATED INFECTION RATE)
}

\author{
HANDIKA LINTANG SAPUTRA, SUTIMIN, SUTRISNO*
}

\begin{abstract}
Abstrak. Tulisan ini membahas analisis kestabilan model penyebaran penyakit tuberkulosis dengan laju infeksi tersaturasi dan efek pengobatannya. Penulis menganalisis perilaku dinamika dari model untuk menyelidiki sifat kestabilan lokal dari titik ekuilibrium model. Kriteria Routh-Hurwitz digunakan untuk menganalisa kestabilan lokal pada titik ekuilibrium bebas penyakit, sedangkan teorema Transcritical Bifurcation digunakan untuk menyelidiki sifat kestabilan lokal dari titik ekuilibrium endemik. Hasil pembahasan menunjukkan bahwa sifat kestabilan dari titik ekuilibrium bergantung pada nilai bilangan reproduksi dasar yang dihitung berdasarkan Next Generation Matrix (NGM). Ketika nilai bilangan reproduksi dasarnya kurang dari satu, maka titik ekuilibrium bebas penyakit bersifat stabil asimtotik lokal, sedangkan jika lebih dari satu, maka titik ekuilibrium endemik bersifat stabil asimtotik lokal. Simulasi numerik disertakan untuk menjelaskan perilaku dinamik dari penyebaran penyakit dan memahami efektifitas pengobatan penyakit tuberkulosis pada suatu populasi tertentu. Hasil simulasi menunjukkan bahwa pengobatan pada fase individu terinfeksi diketahui lebih efektif dari pada pengobatan pada individu laten.
\end{abstract}

Kata-kata kunci: analisis kestabilan, transcritical bifurcation, kriteria Routh-Hurwitz, laju infeksi tersaturasi, tuberkulosis.

2010 Mathematics Subject Classification: 34D20, 34C23, 37M05 


\begin{abstract}
This paper deals with the analysis of tuberculosis disease spread model with saturated infection rate and the treatment effect. We analyze the dynamical behavior of the model to observe the stability property of the model's equilibrium points. The Routh-Hurwitz Theorem is used to analyze the local stability property of the free disease equilibrium point whereas Transcritical Bifurcation theorem is used to analyze the local stability property of the endemic equilibrium point. The results show that the local stability property of the equilibrium points is depending on the basic reproduction number value calculated by the Next Generation Matrix (NGM). When the basic reproduction number is less than 1 , the free disease equilibrium point is locally asymptotically stable, and when it is greater than 1 , the endemic equilibrium point is locally asymptotically stable. Numeric simulation results were presented to describe the evolution of the dynamical behavior and to understand the treatment effectiveness for the tuberculosis disease of the population. From the simulation results, it was derived that the treatment in the infected subpopulation had a better result than the one in latent.
\end{abstract}

Keywords: stability analysis, Routh-Hurwitz criteria, saturated infection rate, transcritical bifurcation, tuberculosis.

\title{
1. PENDAHULUAN
}

Tuberkulosis (TB) secara umum merupakan sebuah penyakit infeksi paruparu yang disebabkan oleh bakteri Mycobacterium Tuberculosis. Penyakit ini tidak hanya terjadi pada paru-paru, melainkan bisa meyerang bagian tubuh lain, seperti tulang belakang, ginjal, otak, sehingga dapat mempengaruhi bagian sistem saraf pusat, sistem limfatik, dan ginjal. Bakteri ini akan ditangkal oleh kekebalan tubuh seorang individu, akan tetapi akan aktif kembali pada saat kekebalan tubuhnya sedang lemah [1]. Sementara dari 56\% estimasi kasus yang ada, Indonesia masuk ke dalam Top Five Countries bersama India, Tiongkok, Filipina dan Pakistan. Organisasi Kesehatan Dunia (WHO) telah mengedarkan laporan kasus TB pertahunnya sejak 1997, dengan tujuan untuk memberikan informasi terkini terhadap perkembangan epidemik TB, pencegahannya, diagnosis dan pengobatan secara global baik di tingkat regional maupun negara, dengan tujuan pada tahun 20162035, menjadi Strategi dan Tujuan Pembangunan Berkelanjutan (SGDs) untuk mengakhiri kasus TB [2]. Oleh karena itu, perlu adanya penanggulangan terhadap penyakit TB secara lebih spesifik.

Selain dari perkembangan ilmu kedokteran dan medis yang berperan penting dalam penanggulangan penyakit tuberkulosis, beberapa bidang yang berbasis bukti penelitian dan riset operasional juga turut andil, salah satunya yaitu bidang teknologi terapan dan epidemologi yang analasisnya tak bisa dipisahkan dari ilmu matematika. Matematika mempunyai peranan yang juga memberikan pengaruh penting dalam pencegahan penyebaran penyakit tuberkulosis, melalui cabang ilmu matematika berupa pemodelan matematika. Dalam pemodelan matematika, pada mulanya banyak digunakan model epidemik yang menggunakan laju 
bilinear insiden, padahal model yang berlaju saturasi insiden, seperti yang telah dikenalkan oleh Esteva dan Matias, cenderung lebih rasional karena mencakup perubahan perilaku dan crowding effect dari individu infektif [3. Saat ini, model saturasi insiden ini sudah mulai banyak digunakan, seperti model yang dibangun oleh Jinhong Zhang 4. Pada model SEIR tersebut Jinhong Zang menerapkan fungsi pengobatan pada fase infected, dengan total jumlah individu pada subpopulasi rentan (suspected) menuju ke fase exposed (tanpa adanya individu rentan yang langsung memasuki fase aktif terinfeksi). Kemudian Soufiane dan Abdelilah juga melakukan analisis fungsi pengobatan non-linier pada fase infected [5. Lebih lanjut, telah dikembangkan model SEIR yang menggunakan fungsi insiden nonlinier dalam [6] yang dikembangkan berdasarkan fungsi insiden linier. Meskipun fungsi insiden non-linier tersebut tidak diterapkan dalam artikel ini, namun topik tersebut menarik untuk dikaji pada penelitian lanjutan di masa mendatang.

Dalam artikel ini, model penyebaran penyakit tuberkulosis dibagi menjadi subpopulasi susceptible (S), exposed (E), Actively-Infected (I) dan Recovery $(R)$ dengan laju infeksi tersaturasi dan titik kesetimbangan dianalisis secara lokal. Penulis mengembangkan model berdasarkan model yang telah dikenalkan oleh Samuel Bowong dan Jean J. Tewa yaitu model penyebaran tuberkulosis dengan subpopulasi susceptible $(S)$, infected $(E)$, Infectious $(I)$ dan Loss of Sight $(L)$ [7. Penggunaan penyebaran penyakit tuberkulosis dengan laju tersaturasi akan memperoleh hasil yang lebih rasional dengan alasan sebagai berikut. Pada model-model klasik, insiden infeksi penyakit dinyatakan oleh simple mass action $\beta S I$ di mana dalam hal ini $\beta$ menyatakan koefisien transmisi. Kemudian untuk menyatakan insiden infeksi terdapat pengembangan model menggunakan insiden standar (stadard incidence) yang dinyatakan oleh $\lambda S I / N$ di mana dalam hal ini $N$ menyatakan total populasi dan $\lambda$ menyatakan tingkat kontak per satuan waktu yang digunakan yan merupakan rata-rata banyaknya insiden kontak per satuan waktu pada individu terinfeksi terhadap individu lain. Pendekatan terhadap insiden infeksi yang lebih lanjut adalah menggunakan saturasi insiden (atau insiden tersaturasi) yang dinyatakan oleh, sebagai contoh, $\lambda S I /\left(c_{S}\right)$ di mana $c$ adalah suatu konstanta. Pendekatan ini dinilai lebih rasional karena ketika ukuran populasi relatif kecil, insiden infeksi diaproksimasi mengikuti fungsi linier tetapi ketika ukuran populasi relatif besar insiden infeksi diaproksimasi bersifat konstan. Sebagai ilustrasi, serangan nyamuk tidak menjadi lebih banyak (diaproksimasi konstan) ketika populasi manusia bertambah dan relatif sangat besar [3].

\section{FORMULASI MODEL}

Alur penyebaran penyakit TB yang diusulkan oleh penulis dalam tulisan ini diilustrasikan pada Gambar 1. Penulis mengembangkan skema tersebut berdasarkan skema yang diusulkan dalam [7. Karakteristik skema penyebaran penyakit dalam 
[7] dijelaskan sebagai berikut: (1) model tidak memuat transmisi dari fase laten $(E)$ langsung ke subpopulasi sembuh $(R),(2)$ model tidak memuat subpopulasi sembuh $(R)$, dan justru memuat subpopulasi individu hilang dari pengawasan $(L)$, (3) pengobatan pada fase laten $(E)$ memungkinkan individu memburuk menjadi terinfeksi dan tidak membahas subpopulasi sembuh, sementara pengobatan pada subpopulasi terinfeksi $(I)$ memungkinkan individu terinfeksi menuju ke masa laten $(E)$ atau menuju ke subpopulasi individu hilang dari pengawasan $(L)$, tetapi individu terinfeksi berpindah ke subpopulasi laten tanpa disertai laju konstan dari subpopulasi terinfeksi. Sedangkan skema yang diusulkan oleh penulis pada Gambar 1. pengobatan $r_{1}$ pada fase laten memungkinkan individu laten $(E)$ dengan laju perubahan $\psi$ untuk bisa menuju subpopulasi sembuh $(R)$ ataupun semakin parah menjadi terinfeksi secara aktif. Pengobatan $r_{2}$ pada fase terinfeksi juga dapat memungkinkan indvidu terinfeksi dengan laju perubahan $\alpha$ untuk menjadi sembuh $(R)$ ataupun sekedar membaik menuju subpopulasi laten $(E)$ dengan laju perubahan $\gamma$. Adapun variabel-variabel dan parameter yang dilibatkan dalam model dapat dilihat pada Tabel 1. Penulis memformulasikan model berdasarkan skema pada Gambar 1 di mana sistem persamaan diferensial yang berlaku dimodelkan sebagai:

$$
\begin{aligned}
\frac{d S}{d t} & =\lambda-\frac{\beta I S}{A+I}-\mu S, \\
\frac{d E}{d t} & =\frac{\beta(1-p) I S}{A+I}+\gamma r_{2} I-(\phi+\mu) E, \\
\frac{d I}{d t} & =\left(1-r_{1}\right) \phi E+\frac{\beta p I S}{A+I}-\left((\alpha+\gamma) r_{2}+\mu+\delta\right) I, \\
\frac{d R}{d t} & =\phi r_{1} E+\alpha r_{2} I-\mu R .
\end{aligned}
$$

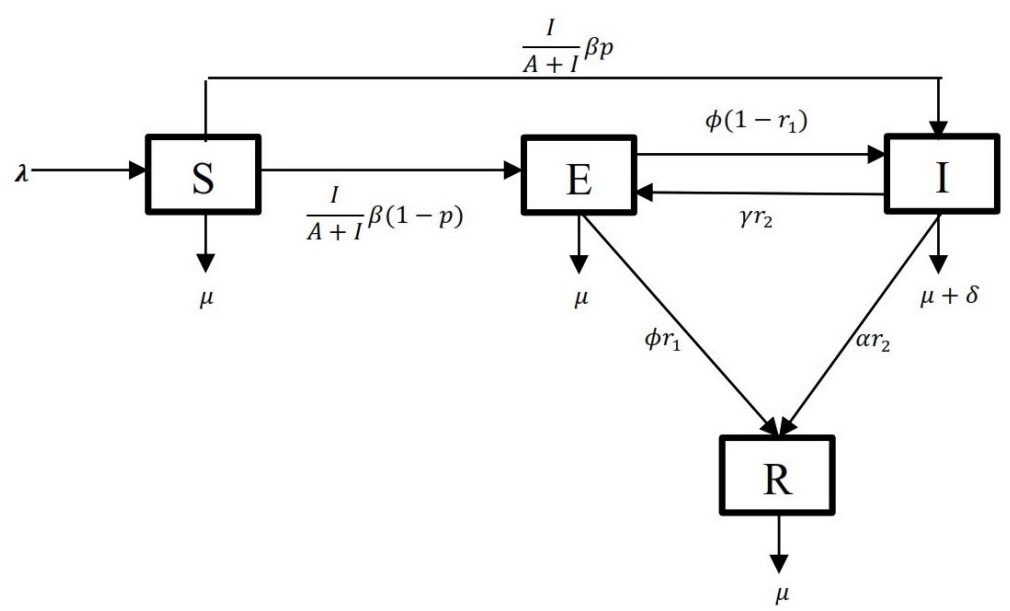

Gambar 1 Skema dinamika populasi 
Tabel 1 Notasi yang digunakan dalam model

\begin{tabular}{ll}
\hline Notasi & Definisi \\
\hline$A \in \mathbb{R}^{+}$ & Faktor saturasi \\
\hline$\lambda \in[0,1]$ & Tingkat rekruitmen populasi \\
\hline$\beta \in[0,1]$ & Tingkat kontak infeksi atau transmisi TB \\
\hline$\phi \in[0,1]$ & $\begin{array}{l}\text { Laju perpindahan individu dari subpopulasi laten ke subpop- } \\
\text { ulasi terinfeksi }\end{array}$ \\
\hline$\alpha \in[0,1]$ & $\begin{array}{l}\text { Laju dari subpopulasi terinfeksi aktif (infected) menjadi sem- } \\
\text { buh }\end{array}$ \\
\hline$\gamma \in[0,1]$ & $\begin{array}{l}\text { Laju perpindahan individu dari subpopulasi terinfeksi ke sub- } \\
\text { populasi laten }\end{array}$ \\
\hline$p \in[0,1]$ & $\begin{array}{l}\text { Proporsi individu di subpopulasi rentan yang berpindah ke } \\
\text { subpopulasi terinfeksi }\end{array}$ \\
\hline $1-p \in[0,1]$ & $\begin{array}{l}\text { Proporsi individu di subpopulasi rentan yang berpindah ke } \\
\text { subpopulasi laten }\end{array}$ \\
\hline$r_{1} \in[0,1]$ & $\begin{array}{l}\text { Tingkat keefektifan pengobatan pada fase laten yang men- } \\
\text { jadikan individu sembuh }\end{array}$ \\
\hline $1-r_{1} \in[0,1]$ & Tingkat pengobatan pada fase laten yang kurang efektif se- \\
& hingga individu menjadi terinfeksi \\
\hline$r_{2} \in[0,1]$ & Tingkat keefektifan pengobatan pada fase terinfeksi \\
\hline$\mu$ & Tingkat kematian alami \\
\hline$\delta \in[0,1]$ & Tingkat kematian akibat TB pada subpopulasi terinfeksi \\
\hline
\end{tabular}

Dalam menganalisis sifat kestabilan titik ekuilibrium model tersebut, diperlukan beberapa lemma berikut.

Lemma 2.1 Misalkan $S(0) \geq 0, E(0) \geq 0, I(0) \geq 0, R(0) \geq 0$, maka solusi $S(t), E(t), I(t), R(t)$ dari Model (2.1) adalah positif untuk setiap $t>0$.

Bukti. Dari Sistem Persamaan (2.1) diketahui:

$$
\frac{d S}{d t}=\lambda-\frac{\beta I}{A+I} S-\mu S=\lambda-\left(\frac{\beta I}{A+I}+\mu\right) S .
$$

Untuk setiap $t>0$, didapat $\frac{d S(t)}{d t}=\lambda-\left(\frac{\beta I(t)}{A+I(t)}+\mu\right) S(t)$. Sehingga

$$
\frac{d S(t)}{d t} e^{\int_{0}^{t}\left(\frac{\beta I(u)}{A+I(u)}+\mu\right) t}+S(t)\left(\frac{\beta I(t)}{A+I(t)}+\mu\right) e^{\int_{0}^{t}\left(\frac{\beta I(u)}{A+I(u)}+\mu\right) t}=\lambda e^{\int_{0}^{t}\left(\frac{\beta I(u)}{A+I(u)}+\mu\right) t}
$$

dan didapatkan 


$$
\begin{aligned}
\frac{d}{d t}\left(S(t) e^{\int_{0}^{t}\left(\frac{\beta I(u)}{A+I(u)}+\mu\right) t}\right)= & \lambda e^{\int_{0}^{t}\left(\frac{\beta I(u)}{A+I(u)}+\mu\right) t} \\
S(t) e^{\int_{0}^{t}\left(\frac{\beta I(u)}{A+I(u)}+\mu\right) t}-S(0)= & \int_{0}^{t} \lambda e^{\int_{0}^{u}\left(\frac{\beta I(u)}{A+I(u)}+\mu\right) t} d u \\
S(t)= & S(0) e^{-\int_{0}^{t}\left(\frac{\beta I(u)}{A+I(u)}+\mu\right) t}+ \\
& e^{-\int_{0}^{t}\left(\frac{\beta I(u)}{A+I(u)}+\mu\right) t} \int_{0}^{t} \lambda e^{\int_{0}^{u}\left(\frac{\beta I(u)}{A+I(u)}+\mu\right) t} d u>0 .
\end{aligned}
$$

Dengan cara yang sama, dapat dibuktikan bahwa $E(t) \geq 0, I(t) \geq 0, R(t) \geq 0$. Oleh karena itu, solusi $S(t), E(t), I(t), R(t)$ dari Model 2.1 adalah positif untuk setiap $t>0$.

Lemma 2.2 Daerah fisibel $\Omega$ yang didefinisikan oleh:

$$
\Omega=\left\{(S(t), E(t), I(t), R(t)) \in R_{+}^{4} \mid 0 \leq S(t)+E(t)+I(t)+R(t) \leq \frac{\lambda}{\mu}\right\}
$$

adalah positif invarian untuk Model 2.1 dengan kondisi awal di $\mathbb{R}_{+}^{4}$.

Bukti. Dengan menambahkan semua persamaan di Sistem Persamaan (2.1), maka diperoleh $\frac{d N}{d t}=\lambda-\mu N-\delta I \leq \lambda-\mu N$. Maka didapatkan juga bahwa $0 \leq N(t) \leq$ $\frac{\lambda}{\mu}+N(0) e^{-\mu t}$, di mana $N(0)$ menyatakan nilai awal populasi. Dengan demikian $\lim _{t \rightarrow \infty} \sup N(t) \leq \frac{\lambda}{\mu}$ yang berarti bahwa daerah

$$
\Omega=\left\{(S(t), E(t), I(t), R(t)) \in R_{+}^{4} \mid 0 \leq S(t)+E(t)+I(t)+R(t) \leq \frac{\lambda}{\mu}\right\}
$$

adalah positif invarian. Akibatnya, Sistem 2.1 adalah terbatas.

\section{ANALISIS KESTABILAN}

Dengan mencari titik-titik ekuilibriumnya, didapat bahwa 2.1) mempunyai titik kesetimbangan bebas penyakit $E_{0}\left(S^{0}, E^{0}, I^{0}\right)=\left(\frac{\lambda}{\mu}, 0,0\right)$, dan titik kesetimbangan endemik $E_{1}\left(S^{*}, E^{*}, I^{*}\right)$ dengan

$$
\left\{\begin{array}{l}
S^{*}=\frac{\lambda\left(A+I^{*}\right)}{A \mu+\mu I^{*}+\beta I^{*}}, \\
E^{*}=\frac{I^{*}\left(A \alpha \mu\left(1-r_{2}\right)+\alpha I^{*}(\beta+\mu)\left(1-r_{2}\right)+\beta \lambda(1-p)\right)}{A \mu^{2}+A \phi \mu+I^{*} \beta \mu+I^{*} \beta \phi+I^{*} \mu^{2}+I^{*} \phi \mu}, \\
I^{*}=\frac{\left(\Re_{0}-1\right) A \mu}{\beta+\mu} .
\end{array}\right.
$$


Dengan menggunakan Metode NGM [10, 11, didapatkan bilangan reproduksi dasar dari Model (2.1) adalah

$$
\Re_{0}=\frac{\beta \lambda\left(p \phi r_{1}+\mu p-\phi r_{1}+\phi\right)}{A \mu\left(\gamma r_{2}\left(\phi r_{1}+\mu\right)+(\mu+\phi)\left(\alpha r_{2}+\delta+\mu\right)\right)} .
$$

Teorema-teorema berikut menjelaskan sifat kestabilan dari titik-titik ekuilibrium yang telah didapat.

Teorema 3.1 Jika $\Re_{0}<1$ maka titik kesetimbangan bebas penyakit $E_{0}\left(S^{0}, E^{0}, I^{0}\right)$ stabil asimtotik lokal. Sebaliknya jika $\Re_{0}>1$, maka $E_{0}\left(S^{0}, E^{0}, I^{0}\right)$ tidak stabil.

Bukti. Linierisasi Model (2.1) di sekitar titik ekuilibrium bebas penyakit menghasilkan matriks Jacobian

$$
J\left(E_{0}\right)=\left[\begin{array}{ccc}
-\mu & 0 & -\frac{\beta \lambda}{A \mu} \\
0 & -\phi-\mu & \frac{\beta(1-p) \lambda}{\mu A}+\gamma r_{2} \\
0 & \phi\left(1-r_{1}\right) & \frac{\beta p \lambda}{A \mu}-(\gamma+\alpha) r_{2}-\mu-\delta
\end{array}\right] .
$$

Misalkan $x$ menyatakan nilai eigen dari (3.1), persamaan karakteristik dari matriks Jacobian tersebut berbentuk polinomial $(x+\mu)\left(x^{2}+a_{1} x+a_{2}\right)=0$, di mana

$$
\begin{aligned}
a_{1}= & \left(1-\Re_{0}\right) \frac{p\left(\gamma r_{2}\left(\phi r_{1}+\mu\right)+(\mu+\phi)\left(\alpha r_{2}+\delta+\mu\right)\right)}{\left(p \phi r_{1}+\mu p+\phi\left(1-r_{1}\right)\right)} \\
& +\frac{\phi r_{2}\left(1-r_{1}\right) \gamma}{\left(p \phi r_{1}+\mu p+\phi\left(1-r_{1}\right)\right)}+\frac{r_{2}\left(-1+r_{1}\right)(-1+p) \phi \alpha+\phi\left(-1+r_{1}\right)(-1+p) \delta}{\left(p \phi r_{1}+\mu p+\phi\left(1-r_{1}\right)\right)} \\
& +\frac{2 \mu p \phi r_{1}+p \phi^{2} r_{1}+\mu^{2} p+\phi^{2}\left(1-r_{1}\right)+2 \mu \phi\left(1-r_{1}\right)}{\left(p \phi r_{1}+\mu p+\phi\left(1-r_{1}\right)\right)}, \\
a_{2}= & \left(1-\Re_{0}\right)\left(\gamma \phi r_{1} r_{2}+\alpha \mu r_{2}+\alpha \phi r_{2}+\gamma \mu r_{2}+\delta \mu+\delta \phi+\mu^{2}+\mu \phi\right) .
\end{aligned}
$$

Diperoleh eigen $x_{1}=-\mu<0$, dan nilai-nilai eigen lainnya $x_{2}, x_{3}$ akan bernilai negatif jika $a_{1}>0$ dan $a_{1} a_{2}>0$ yang terpenuhi ketika $1-\Re_{0}>0 \leftrightarrow \Re_{0}<1$. Berdasarkan kriteria Routh-Hurwitz, hasil tersebut menyimpulkan bahwa ekuilibrium $E_{0}$ bersifat stabil asimtotik lokal.

Teorema 3.2 Jika $\Re_{0}>1$ maka titik ekuilibrium endemik $E_{1}\left(S^{*}, E^{*}, I^{*}\right)$ bersifat stabil asimtotik lokal.

Bukti. Analisis bifurkasi dalam [10] dan Teori Manifold Center dalam [11] digunakan dalam pembuktian ini. Asumsikan $\Re_{0}=1$ dan pilih $\beta=\beta^{*}$ menjadi parameter bifurkasi pada persamaan $\Re_{0}$ sehingga diperoleh

$$
\beta^{*}=\frac{A \mu\left(\gamma r_{2}\left(\phi r_{1}+\mu\right)+(\mu+\phi)\left(\alpha r_{2}+\delta+\mu\right)\right)}{\lambda\left(p \phi r_{1}+\mu p+\phi\left(1-r_{1}\right)\right)} .
$$


Nilai matriks Jacobian Sistem 2.1 saat $\beta=\beta^{*}$ adalah

$$
J\left(E_{0}, \beta^{*}\right)=\left[\begin{array}{ccc}
-\mu & 0 & -\frac{\left(\gamma r_{2}\left(\phi r_{1}+\mu\right)+(\mu+\phi)\left(\alpha r_{2}+\delta+\mu\right)\right)}{\left(p \phi r_{1}+\mu p+\phi\left(1-r_{1}\right)\right)} \\
0 & -\phi-\mu & \frac{\left(\gamma r_{2}\left(\phi r_{1}+\mu\right)+(\mu+\phi)\left(\alpha r_{2}+\delta+\mu\right)\right)}{\left(p \phi r_{1}+\mu p+\phi\left(1-r_{1}\right)\right)}(1-p)+\gamma r_{2} \\
0 & \phi\left(1-r_{1}\right) & \frac{\left(\gamma r_{2}\left(\phi r_{1}+\mu\right)+(\mu+\phi)\left(\alpha r_{2}+\delta+\mu\right)\right)}{\left(p \phi r_{1}+\mu p+\phi\left(1-r_{1}\right)\right)} p-(\gamma+\alpha) r_{2}-\mu-\delta
\end{array}\right] .
$$

Nilai eigen dari matriks Jacobian tersebut adalah $x_{1}=-\mu, x_{2}=0$, dan

$$
\begin{aligned}
x_{3}= & -\frac{\phi r_{2}\left(-1+r_{1}\right)(-1+p) \alpha}{\left(p \phi r_{1}+\mu p+\phi\left(1-r_{1}\right)\right)}-\frac{\phi\left(-1+r_{1}\right)(-1+p) \delta}{\left(p \phi r_{1}+\mu p+\phi\left(1-r_{1}\right)\right)}-\frac{\phi\left(1-r_{1}\right) r_{2} \gamma}{\left(p \phi r_{1}+\mu p+\phi\left(1-r_{1}\right)\right)} \\
& -\frac{2 \mu p \phi r_{1}+p \phi^{2} r_{1}+\mu^{2} p+2 \mu \phi\left(1-r_{1}\right)+\phi^{2}\left(1-r_{1}\right)}{\left(p \phi r_{1}+\mu p+\phi\left(1-r_{1}\right)\right)} .
\end{aligned}
$$

Matriks Jacobian $J\left(E_{0}, \beta^{*}\right)$ mempunyai nilai eigen sederhana $x_{2}=0$, untuk itu vektor eigen kanan yang bersesuaian dengan nilai eigen $x_{2}=0$ dapat dinotasikan dengan $w=\left[\begin{array}{lll}w_{1} & w_{2} & w_{3}\end{array}\right]^{T}$ yang mana vektor eigen kanan harus memenuhi

$$
J\left(E_{0}, \beta^{*}\right) w=0
$$

dan diperoleh nilai vektor eigen kanannya yaitu

$$
w=\left[\begin{array}{lll}
-\frac{\left(\gamma r_{2}\left(\phi r_{1}+\mu\right)+(\mu+\phi)\left(\alpha r_{2}+\delta+\mu\right)\right) w_{3}}{\left(p \phi r_{1}+\mu p+\phi\left(1-r_{1}\right)\right) \mu} & \frac{\left(\alpha r_{2}(1-p)+\delta(1-p)+\gamma r_{2}+\mu(1-p)\right) w_{3}}{\left(p \phi r_{1}+\mu p+\phi\left(1-r_{1}\right)\right)} & w_{3}
\end{array}\right]^{\top} .
$$

Kemudian dicari vektor eigen kiri yang bersesuaian dengan nilai eigen $x_{3}=0$ yang dinotasikan dengan $v=\left[\begin{array}{lll}v_{1} & v_{2} & v_{3}\end{array}\right]$. Vektor eigen kiri $v$ memenuhi

$$
v \cdot J\left(E_{0}, \beta^{*}\right)=0,
$$

yaitu $\left[\begin{array}{lll}v_{1} & v_{2} & v_{3}\end{array}\right]=\left[\begin{array}{lll}0 & \frac{v_{3} \phi\left(1-r_{1}\right)}{\phi+\mu} & v_{3}\end{array}\right]$. Kemudian dicari nilai $w_{3}$ dan $v_{3}$ yang memenuhi $v \cdot w=1$, dan diperoleh

$$
\begin{aligned}
& w_{3}=\frac{1}{\left(\begin{array}{l}
\phi\left(1-r_{1}\right) \mu(1-p)+(\phi+\mu)\left(\phi r_{1}+\mu\right) p+\phi\left(1-r_{1}\right)(\phi+\mu) \\
+\phi\left(1-r_{1}\right)\left(\alpha r_{2}(1-p)+\gamma r_{2}+\delta(1-p)\right)
\end{array}\right)}>0, \\
& v_{3}=(\phi+\mu)\left(\phi r_{1}+\mu\right) p+\phi\left(1-r_{1}\right)(\phi+\mu)>0 .
\end{aligned}
$$

Misalkan $S=y_{1}, E=y_{2}$, dan $I=y_{3}$ maka Sistem Persamaan 2.1 dapat ditulis sebagai

$$
\left\{\begin{array}{l}
\frac{d y_{1}}{d t}=\lambda-\frac{\beta y_{3}}{A+y_{3}} y_{1}-\mu y_{1}=f_{1} \\
\frac{d y_{2}}{d t}=\frac{\beta(1-p) y_{3}}{A+y_{3}} y_{1}+\gamma r_{2} y_{3}-(\phi+\mu) y_{2}=f_{2}, \\
\frac{d y_{3}}{d t}=\left(1-r_{1}\right) \phi y_{2}+\frac{\beta p y_{3}}{A+y_{3}} y_{1}-\left((\alpha+\gamma) r_{2}+\mu+\delta\right) y_{3}=f_{3} .
\end{array}\right.
$$


Turunan parsial tingkat dua dari sistem persamaan di atas pada titik kesetimbangan bebas penyakit $E_{0}\left(S^{0}, E^{0}, I^{0}\right)=E_{0}\left(y_{1}{ }^{0}, y_{2}{ }^{0}, y_{3}{ }^{0}\right)=\left(\frac{\lambda}{\mu}, 0,0\right)$ adalah

$$
a=\sum_{k, i, j=1}^{3} v_{k} w_{i} w_{j} \frac{\partial^{2} f_{k}}{\partial y_{i} \partial y_{j}}\left(E_{0}, 0\right) \text {. }
$$

Karena $v_{1}=0$ didapat

$$
\begin{aligned}
a= & -\frac{2 \beta(1-p) v_{3} \phi\left(1-r_{1}\right)\left(\gamma \phi r_{1} r_{2}+\alpha \mu r_{2}+\alpha \phi r_{2}+\gamma \mu r_{2}+\delta \mu+\delta \phi+\mu^{2}+\mu \phi\right) w_{3}^{2}}{A(\phi+\mu)\left(p \phi r_{1}+\mu p+\phi\left(1-r_{1}\right)\right) \mu} \\
& -\frac{2 \beta(1-p) \lambda v_{3} \phi\left(1-r_{1}\right) w_{3}^{2}}{\mu A^{2}(\phi+\mu)}-\frac{2 \beta(1-p) \lambda v_{3} w_{3}^{2}}{\mu A^{2}} \\
& -\frac{2 \beta p v_{3}\left(\gamma \phi r_{1} r_{2}+\alpha \mu r_{2}+\alpha \phi r_{2}+\gamma \mu r_{2}+\delta \mu+\delta \phi+\mu^{2}+\mu \phi\right) w_{3}^{2}}{A\left(p \phi r_{1}+\mu p+\phi\left(1-r_{1}\right)\right) \mu}-\frac{2 \beta p \lambda v_{3} w_{3}^{2}}{\mu A^{2}} \\
& <0
\end{aligned}
$$

dan

$$
b=\sum_{k, i=1}^{3} v_{k} w_{i} \frac{\partial^{2} f_{k}}{\partial y_{i} \partial \beta^{*}}\left(E_{0}, 0\right)=\frac{(1-p) \lambda \phi\left(1-r_{1}\right) v_{3} w_{3}}{A \mu(\phi+\mu)}+\frac{p \lambda v_{3} w_{3}}{A \mu}>0 .
$$

Berdasarkan Teori Manifold Center, karena $a<0$ dan $b>0$, hal ini menunjukkan Sistem (2.1) mengalami bifurkasi transcritical pada saat $\Re_{0}=1$, dan terjadi pertukaran kestabilan dari kestabilan titik kesetimbangan bebas penyakit berubah menjadi titik kesetimbangan endemik, yaitu ketika $\Re_{0}>1$. Artinya, titik kesetim-

\begin{tabular}{|c|c|c|c|c|c|c|c|}
\hline Parameter & $A$ & $\lambda$ & $\beta$ & $\phi$ & $\alpha$ & $\gamma$ & $p$ \\
\hline Nilai & 0,8 & 0,08 & 0,04 & 0,005 & 0,02 & 0,01 & 0,3 \\
\hline Sumber & [4] & 8 & [4] & [7] & [7] & generated & [7] \\
\hline Parameter & $1-p$ & $r_{1}$ & $1-r_{1}$ & $r_{2}$ & $\mu$ & $\delta$ & \\
\hline Nilai & 0,7 & 0,9706 & 0,0294 & 0,1818 & 0,0101 & 0,022722 & \\
\hline Sumber & 7 & 9 & 9 & {$[7]$} & [7] & [7] & \\
\hline
\end{tabular}
bangan endemik $E_{1}\left(S^{*}, E^{*}, I^{*}\right)$ bersifat stabil asimtotik local ketika $\Re_{0}>1$.

\section{SIMULASI NUMERIK}

Pada bagian ini, diberikan hasil simulasi numerik menggunakan nilai parameter pada Tabel 2 .

Tabel 2 Nilai parameter dalam simulasi numerik 


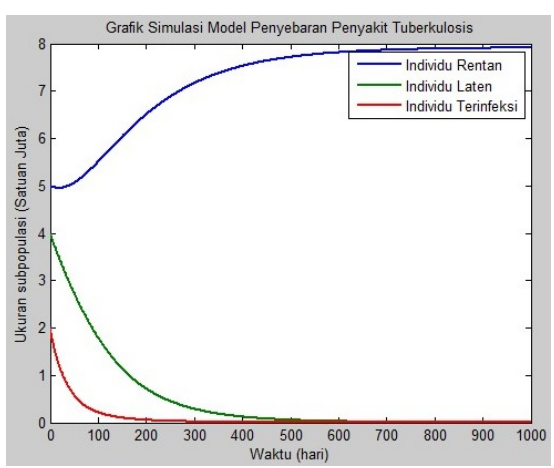

(a) Grafik hasil simulasi $\Re_{0}=0,829$.

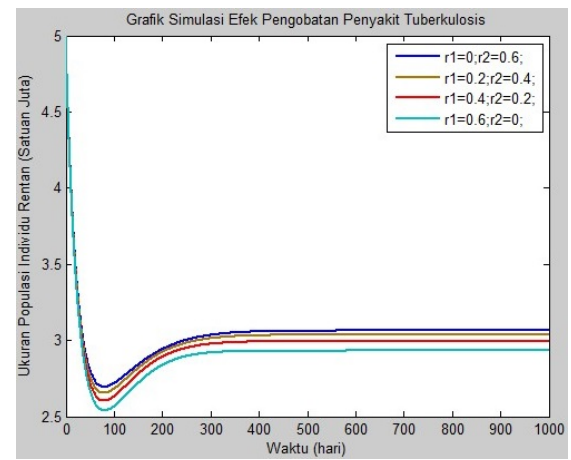

(c) Grafik hasil simulasi dengan nilai $r_{1}$ dan $r_{2}$ bervariasi

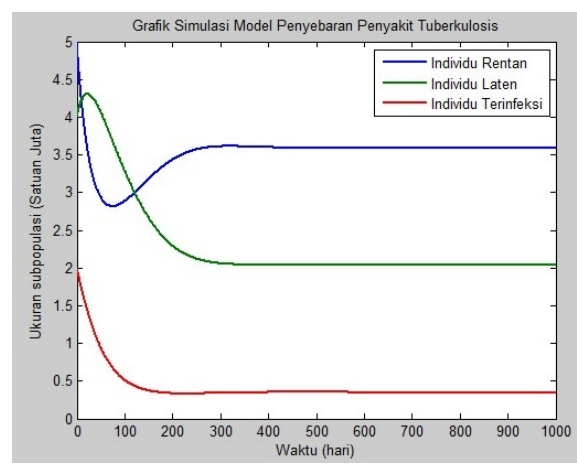

(b) Grafik hasil simulasi dengan $\Re_{0}=3,1760$

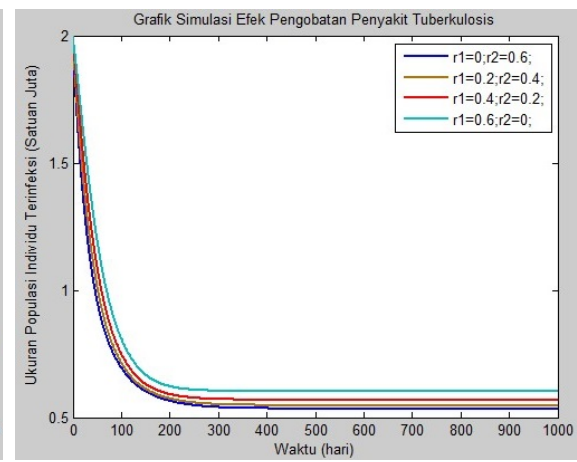

(d) Grafik hasil simulasi dengan nilai $r_{1}$ dan $r_{2}$ bervariasi

Gambar 2 Grafik dinamika populasi hasil simulasi

Pertama, dengan $\beta=0,01$ per tahun menghasilkan $\Re_{0}=0,8297362736<1$, maka menurut Teorema 3.1 titik ekuilibrium bebas penyakit bersifat stabil asimtotik lokal. Gambar 2(a) mengilustrasikan dinamika dari populasi pada kondisi ini. Kedua, dengan $\beta=0,04$ per tahun yang diambil dari Referensi 4] menghasilkan nilai $\Re_{0}=3,176061549>1$, dan menurut Teorema, titik ekuilibrium endemik bersifat stabil asimtotik lokal. Gambar 2(b) mengilustrasikan dinamika populasi pada kondisi ini. Ketiga, dengan menggunakan variasi nilai porsi pengobatan pada fase laten $r_{1}$ dan pengobatan pada fase terinfeksi $r_{2}$, menimbulkan berbagai efek yang terjadi terhadap subpopulasi individu rentan sesuai hasil pada Gambar 2(c). dan berpengaruh terhadap subpopulasi terinfeksi yang sesuai hasil pada Gambar 2(d). Hal ini dapat dijadikan pertimbangan jika permasalahan dihadapkan pada keadaan harus memilih mengobati individu laten atau terinfeksi. Dari Gambar 2(c) dan 2(d) dapat dilihat bahwa besar porsi pengobatan (yang sebanding dengan tingkat keefektifan) pada populasi terinfeksi dan sebaliknya semakin kecil 
porsi pengobatan pada populasi laten, menghasilkan populasi terinfeksi yang semakin sedikit. Begitu pula sebaliknya. Artinya, pengobatan pada fase terinfeksi lebih baik untuk diprioritaskan.

\section{PENUTUP}

Pada tulisan ini, telah dianalisis sifat kestabilan dari titik ekuilibrium pada model penyebaran penyakit tuberculosis dengan laju infeksi tersaturasi dan dengan dua pengobatan, yaitu pengobatan pada subpopulasi individu laten dan pengobatan pada subpopulasi individu terinfeksi. Diketahui bahwa titik kesetimbangan bebas penyakit bersifat stabil asimtotik lokal ketika nilai bilangan reproduksi dasar kurang dari 1 dan titik kesetimbangan endemik penyakit bersifat stabil asimtotik lokal ketika nilai bilangan reproduksi dasar lebih dari 1. Untuk mengetahui efek dari pengobatan pada fase laten dan pengobatan pada fase terinfeksi terhadap individu rentan dan terinfeksi, telah digambarkan variasi porsi pengobatan. Hasil menunjukkan bahwa pengobatan pada fase terinfeksi disarankan untuk diprioritaskan.

Penelitian lebih lanjut menarik dilakukan jika model dikembangkan menggunakan fungsi saturasi daripada menggunakan koefisien saturasi. Kemudian, analisis kestabilan global juga dapat diteliti untuk titik kesetimbangan baik bebas penyakit maupun endemik. Lebih lanjut, untuk hasil yang lebih akurat, data pada simulasi dapat menggunakan data observasi lapangan pada suatu populasi.

\section{REFERENSI}

[1] Whang, S., Choi, S. and Jung, E., A dynamic model for tuberculosis transmission and optimal treatment strategies in South Korea, J. Theor. Biol., 279 (2011), 120-31.

[2] World Health Organization, Global Tuberculosis Report 2018, World Health Organization (2018), https://apps .who.int/iris/handle/10665/274453

[3] Esteva, L. and Matias, M., A Model for Vector Transmitted Diseases with Saturation Incidence, J. Biol. Syst., 9 (2001), 235-245.

[4] Zhang, J., Jia, J., and Song, X., Analysis of an SEIR epidemic model with saturated incidence and saturated treatment function, Sci. World J., 2014 (2014), 1-11.

[5] Elkhaiar, S. and Kaddar, A., Stability Analysis of an SEIR Model with Treatment, Res. Appl. Math., 1 (2017), 1-16.

[6] Fengying Wei, Rui Xue, Stability and extinction of SEIR epidemic models with generalized nonlinear incidence, Mathematics and Computers in Simulation, 170 (2020), 1-15.

[7] Bowong, S.and Tewa, J. J., Mathematical analysis of a tuberculosis model with differential infectivity, Commun. Nonlinear Sci. Numer. Simul., 14 (2009), 4010-4021.

[8] Huo, H. F. and Zou, M. X., Modelling effects of treatment at home on tuberculosis transmission dynamics, Appl. Math. Model., 40 (2016), 9474-9484.

[9] Kim, S., de los Reyes, A. A. and Jung, E., Mathematical model and intervention strategies for mitigating tuberculosis in the Philippines, J. Theor. Biol., 443 (2018), 100-112. 
[10] Yang, H. M., The basic reproduction number obtained from Jacobian and next generation matrices - A case study of dengue transmission modelling, BioSystems, 126 (2014), 52-75.

[11] Van Den Driessche, P. and Watmough, J., Reproduction numbers and sub-threshold endemic equilibria for compartmental models of disease transmission, Math. Biosci., 180 (2002), 2948.

[12] Gunawan, Bifurkasi Mundur pada Model Epidemi SEIV dengan Laju Insiden Nonlinear, $J$. Mat. Murni dan Terap. Epsilon, 10 (2016), 1-13.

[13] Manda, E. C., Within Host Dynamics for Treatment of R5 HIV Infection in the Langerhans, $\mathrm{PhD}$ Thesis, African Institute for Mathematical Sciences (AIMS), 2015.

\section{HANDIKA LinTANG SAPUTRA}

Departemen Matematika, Universitas Diponegoro, Semarang, Indonesia. handikalsaputra@gmail.com

\section{Sutimin}

Departemen Matematika, Universitas Diponegoro, Semarang, Indonesia. sutimin@undip.ac.id

\section{Sutrisno* (Penulis korespondensi)}

Departemen Matematika, Universitas Diponegoro, Semarang, Indonesia. tresno.math@live.undip.ac.id 